\title{
The Relationship of Education and Regional Income Level on Environmental Quality: Empirical Evidence from High Populated Country
}

\author{
Fakhri Adrian \\ Department of Economics, Faculty of Economics and Business, Universitas Indonesia \\ Depok, Indonesia
}

\section{Khoirunurrofik Khoirunurrofik ${ }^{1}$}

Department of Economics, Faculty of Economics and Business, Universitas Indonesia Depok, Indonesia

\author{
Received : $\quad$ 27 January 2021 \\ Accepted : 23 July 2021
}

Available Online : 31 August 2021

\begin{abstract}
Indonesia is committed to implementing a sustainable development agenda by considering its quality and maintaining economic growth by improving public education and regional income. This study aims to estimate the relationship between education and regional income level with the environmental quality of Indonesian provinces. By applying the descriptive analysis and panel data regression, it is observed that regions with a high-level level of education and income are likely to have low environmental quality, which shows that education level has a negative relationship with environmental quality. In contrast, income level has no relationship with environmental quality. The empirical estimation revealed that higher education and regional income correlate with a lower level of environmental quality. It implied that the regional development in Indonesia has been at the cost of environmental degradation. It advised establishing an incentive and disincentive mechanism for economic actors to utilize energy resources and environmentally friendly production technology and bring the country into a sustainable development direction.
\end{abstract}

Keywords: education level; environmental quality; generalized least-square; income level; Indonesia; panel data regression; sustainable development

\section{Introduction}

In 2015, in a historic effort to foster international cooperation, 193 United Nations (UN) member states had adopted the 2030 Agenda with 17 Sustainable Development Goals (SDGs) (Kroll \& Zipperer, 2020). Many organizations worldwide play a crucial role in advancing the agenda for sustainable development (Salvia et al., 2019). The SDGs evolved from a sustainability aspect into various pillars to cover the complexity and linkages between developments (Zinkernagel et al., 2018). The SDGs are spanned on a multidimensional basis globally, in which the implementation depends on the country's

\footnotetext{
${ }^{1}$ Corresponding Author: Department of Economics, Faculty of Economics and Business, Universitas Indonesia Depok, Indonesia.

Email: khoirunurrofik@ui.ac.id
}

Adrian, F., \& Khoirunurrofik, K. (2021). The relationship of education and regional income level on environmental quality: Empirical evidence from high populated country. Jurnal Wilayah dan Lingkungan, $9(2)$, 186-197. doi:10.14710/jwl.9.2.186-197. 
priorities and how the issues of the SDGs compete with the country's strategic issues (Lima et al., 2017; Salvia et al., 2019; Scheyvens et al., 2016). SDGs require a concerted and coordinated effort to move from internationally driven development projects to operationsdriven locally and regionally (Patole, 2018).

In implementing sustainable development at the national level, the Minister of National Development Planning of Indonesia has stated that Indonesia is committed to achieving the SDGs (Bappenas, 2019). Environmental, social, and economic aspects must be integrated into a development strategy to drive sustainable development (Law 32 of 2009 on Environmental Protection and Management). Presidential Regulation Number 59 of 2017 concerning the Implementation of Achieving the Sustainable Development Goals has proven that Indonesia is committed to implementing the SDGs. The presidential regulation stated that the basis for implementing the principles of sustainable development is inclusive, and no one is left behind. The commitment to planning national dan regional development strategies in a sustainable direction has been mandated in Article 2 paragraph (1) of Law 25 of 2004 concerning the National Development System, and policies in Article 262 paragraph (1) of Law 23/2014 on Regional Government.

Indonesia has several challenges to achieving sustainable development. First, Indonesia has entered into the middle-income trap (Lubis \& Saputra, 2016). Basri et al. (2016) stated that the Indonesian economy has shown remarkable progress in the last four decades. Indonesia's economic growth recovered after the currency crisis that devastated the economy from 1998 to 1999 with commodity prices. Therefore, Indonesia has become one of the largest middle-income countries in the world. As Chan (2014) has said, various structural challenges and limitations on its long-term growth prospects leave the country caught in the middle-class income trap. Based on the appendix to Presidential Regulation 18/2020 concerning Indonesia's National Medium Term Development Plan 2020-2024, Indonesia is experiencing difficulties to continue the socio-economic transformation that has been postponed since the monetary crisis hit in 1997-1998. After 1998, it turned out that Indonesia's structural transformation was still slow. Indonesia experienced stagnant economic growth, where Indonesia's average economic growth in the year 1961-2019 was 5.26 percent. Economic growth in the period 1990-2000 was in the range of 6 percent, but in the period 2000-2015, it decreased in the range of 5 percent. In 2018, the primary, secondary, and tertiary sectors had contributed 20.9 percent, 19.9 percent, and 59.2 percent to GDP, respectively.

Second, there is a problem with a low-educated workforce. A country's per capita income can be improved by increasing government expenditure, investment spending, high technology exports, and human capital (Lubis \& Saputra, 2016). Compared to most middleincome countries, Indonesia is left behind in building its human resource stock (Basri et al., 2016). Based on the attachment to Presidential Regulation Number 18 of 2020 concerning the National Medium-Term Development Plan of 2020-2024, the service sector's contribution to GDP does not drive significant economic growth. The informal service sector dominates the proportion of workers in the service sector. However, the informal sector has a low contribution to economic growth. Meanwhile, the secondary sector, which has a high potential to stimulate economic growth, faces the challenge of increasing labor wages that have not been followed by equal productivity. This low productivity problem is related to the low quality of human resources, which primary school graduates still dominate the workforce (see Figure 1). 


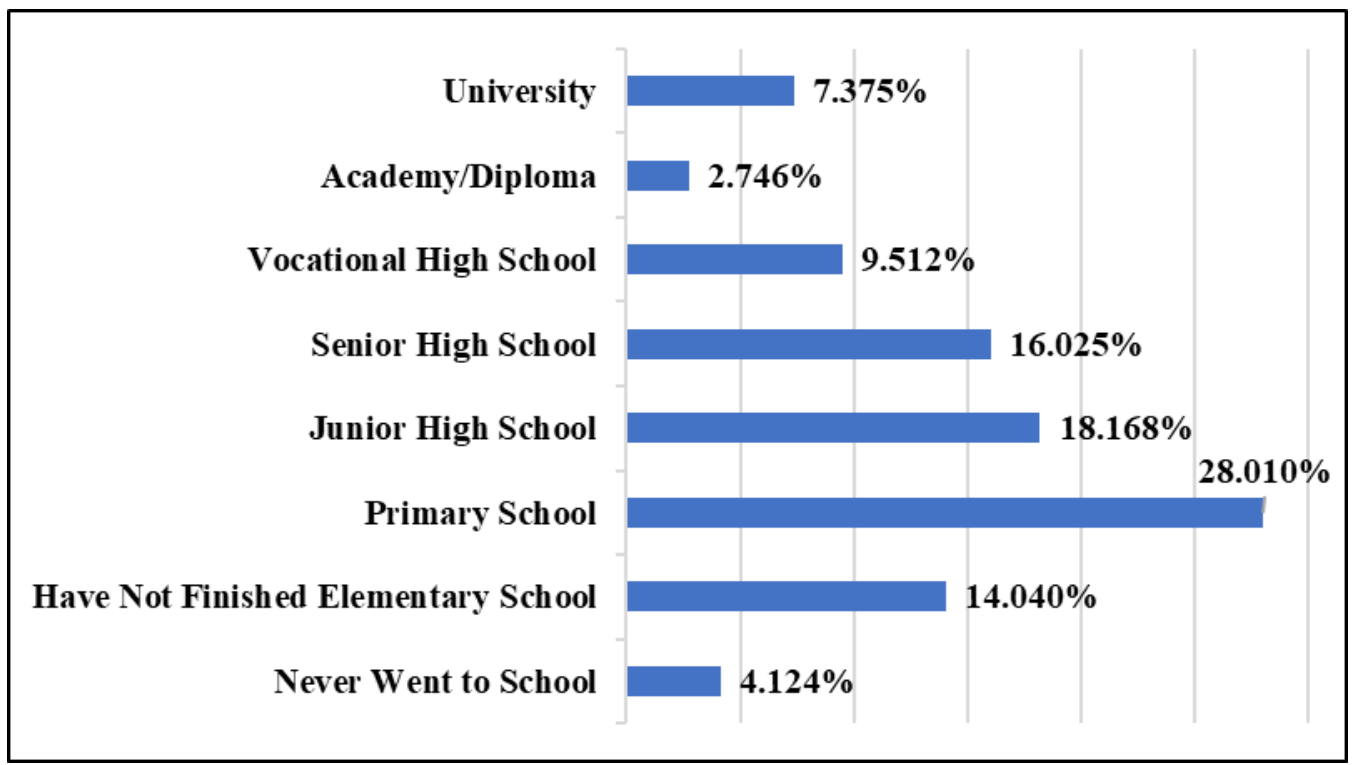

Source: BPS, 2020

\section{Figure 1. Average Population Aged 15 Years and Over Whom Work According to Highest Education Enforced in 2008-2020 in Indonesia}

Third, Indonesia has experienced a degradation in the environment's quality, hindering sustainable economic growth. In Indonesia, carbon emissions have increased by 26 times from 1960, with a total carbon emission of 21,404.3 kilo tonnes to 2016, with a total carbon emission of 564,324.5 kilo tonnes (Worldbank, 2020). It indicates there was environmental degradation in Indonesia from 1960 to 2016. Then, there were fluctuations in the quality of the environment in Indonesia from 2011-2018. Based on the data of Indonesia's Environmental Quality Index (EQI) value from 2011-2018, which was processed based on the EQI report published by the Ministry of Environment and Forestry published in 2014-2018, the quality of Indonesia's environment from 2011 to 2018 was categorized at adequate category level of environmental quality. In 2018, Indonesia's environment was considered good environmental quality, while in 2013 was Indonesia's worst environmental quality between 2011 and 2018, with an EQI value of 63.2 points. Even though it was an increase in 2018, the quality of Indonesia's environment has generally shown slight improvement. It needs more progressive efforts to repair and control environmental damage to achieve the expected future results. The national EQI trend shows that water quality is getting worse, air quality is decreasing in absolute terms, and only the quality of land cover has improved. In the appendix to Presidential Regulation Number 18 of 2020 concerning the National Mid-term Development Plan of 2020-2024, a decrease in the environmental quality and depletion of natural resources can hamper Indonesia's economic growth sustainably because Indonesia's economy still depends on the natural resource sector.

According to literature, in the early stages of development, the increasing of education level and increasing income level will cause environmental degradation (Baek, 2016; Balaguer \& Cantavella, 2018; Kasman \& Duman, 2015; Kurniawan \& Managi, 2018; L. Li et al., 2019; Waslekar, 2014; Yazdi \& Dariani, 2019; Zafar et al., 2020; Zhang et al., 2017) and would be changed with an increase in higher education and higher income, people's lifestyle and consumption will change in sustainable direction toward the improvement of the environmental quality (Ahmed et al., 2020; Baek, 2016; Balaguer \& 
Cantavella, 2018; Hoang \& Kato, 2016; Hove \& Tursoy, 2019; Kahyaoğlu, 2014; Kasman \& Duman, 2015; Kurniawan \& Managi, 2018; Rahman \& Vu, 2020; Sumargo, 2018; Tianyu \& Meng, 2020; Varela-Candamio et al., 2018; Waslekar, 2014; Yao et al., 2019; Yazdi \& Dariani, 2019; Zafar et al., 2020; Zhang et al., 2017; Zsóka et al., 2013). Based on previous research statements, a hypothesis has emerged: increasing education and increasing income can improve the environment's quality. If this hypothesis is proven to be in accordance with the conditions that occur in Indonesia, then efforts to increase education and community income can accelerate the process to achieve Indonesia's SDGs.

This study aims to estimates the relationship between education and income level with environmental quality at the provincial level of a high population country, like Indonesia. Furthermore, this study also contributes to the enrichment of the existing literature. In the context of Indonesia, this study is the first attempt to identify and analyze the relationship between education level (current and future conditions) and income level (current and future conditions) to environmental quality (environmental quality index, water quality index, air quality index, and land cover quality index). The study used the environmental quality indicator, representing the reality of environmental conditions in a particular region due to the air, water, and land cover quality. Previously, only carbon emission was being used to indicate the quality of environmental conditions. This study then envisioned the square of economic growth on the environment's quality and the relationship with the environment when education is improved in the future with carefully adopted a suitable methodology to solve the autocorrelation and heteroscedasticity problems in panel data regression models. Finally, we provide policy recommendations for the Indonesian government to develop the country into a sustainable development direction.

\section{Research Methods}

This research applied a panel data regression method to analyze the relationship between education and income against regions' environmental quality. Panel regression models are organized by panel data consisting of observations on the same cross-sectional units, or individuals, over several periods (Gujarati \& Porter, 2013). The advantage of using panel data can increase the sample size significantly. Panel data is more suitable for capturing the dynamics of change because it represents repeated cross-sectional observations. Next, panel data allows us to examine more complex behavioral models. On the other hand, panel data has several problems in estimating actual conditions because it involves cross-sectional dimensions and time. The problem that often occurs in crosssectional data is heteroscedasticity, and in time-series data is autocorrelation.

Moreover, there are some additional problems, such as cross-correlation in individual units at the same time. Gujarati \& Porter (2013) have stated that a good estimation model must meet the best linear unbiased estimator (BLUE). Generalized Least Square (GLS) methods can meet the best linear unbiased estimator's panel data model (Setyawan et al., 2019). The GLS estimation method is applied by adding weight to the parameters experiencing heteroscedasticity problems. Then, the GLS estimator has a more minimum variance than the Ordinary Least Squares (OLS) estimator. The GLS estimator is more efficient than the OLS estimator. GLS models remain triumphant compared to OLS models because the method can overcome heteroscedasticity. Thus, to eliminate heteroscedasticity and autocorrelation problems in panel data regression, the best estimator to be used is the GLS method. 


\section{Model Specifications}

Based on the previous research, increasing education and income levels will cause environmental degradation in the early stages. However, increasing higher education and higher income will change people's lifestyle and consumption in a sustainable direction; thus, the environmental quality will be improved. However, population growth, expanding urbanization, and increasing household consumption will worsen the environment's quality (Liang \& Yang, 2019; Rahman, 2017; Yazdi \& Dariani, 2019). Thus, environmental, water, air, and land cover quality are the dependent variables. The mean years of schooling, the square of mean years of schooling, the level of Gross Regional Domestic Product (GRDP) per capita, and the square of GRDP per capita are used as independent variables. Household consumption, urbanization rate, and population are used as control variables. There are four research models, namely the environmental quality model that structured with natural logarithmic form in equation (1), the water quality model structured in equation (2), the air quality model structured in equation (3), and the land cover quality model structured in equation (4).
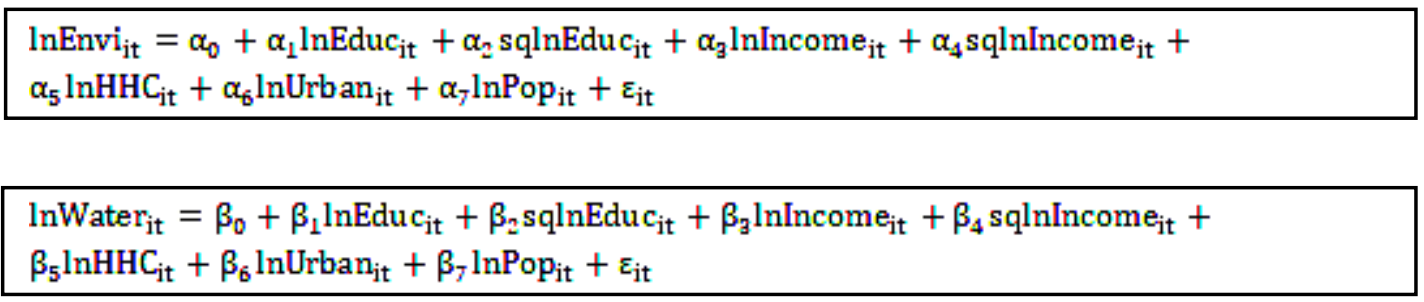

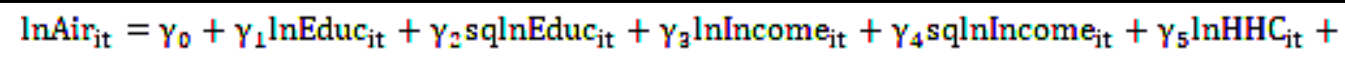
$\gamma_{6} \operatorname{lnUrban}_{\text {it }}+\gamma_{6} \ln$ Pop $_{\text {it }}+\varepsilon_{\text {it }}$

$\operatorname{lnLand}_{\mathrm{it}}=\delta_{0}+\delta_{1} \operatorname{lnEduc}_{\mathrm{it}}+\delta_{2} \operatorname{lnIncome}_{\mathrm{it}}+\delta_{\mathrm{a}}$ sqlnIncome $_{\mathrm{it}}+\delta_{4} \operatorname{lnHHC}_{\mathrm{it}}+$ $\delta_{5} \ln _{\text {urban }}+\delta_{\text {it }} \ln$ Popit $_{i t}+\varepsilon_{\text {it }}$

From equations (1) to (4), all variables transformed to the natural logarithm to make moderately skewed data toward normally distributed and follow the classic assumption of OLS method. lnEnvi is the natural logarithm of the environmental quality index (EQI) within one province. While lnWater is the natural logarithm of the water quality index (WQI) within one province. Furthermore, lnAir is the natural logarithm of the air quality index (AQI) within one province. lnLand is the natural logarithm of the land cover quality index (LCQI) within one province. The independent variables used in equations (1) to (4) are the same because the AQI, WQI, and LCQI are input values for the EQI. lnEduc is the natural logarithm of mean years of schooling within one province. sqlnEduc is the square of natural logarithm of mean years of schooling, the square form is used to show conditions when there is a two-fold increase in the future compared to current conditions by counting $\left((\ln (\mathrm{x}))^{2}\right)$. Meanwhile, lnIncome is the natural logarithm of GRDP per capita at constant 2010 prices within one province, and sqlnIncome is the square of natural logarithm of GRDP per capita at constant prices in 2010 within one province. lnHHC is the natural logarithm of household consumption expenditure at constant 2010 prices within one province. lnUrban is the natural logarithm of the percentage of the urban population within one province. Finally, lnPop is the natural logarithm of the population within one province. 
Authors hypothesize that increases in education and income level are initially negatively related to environmental quality $\left(\alpha_{1}<0 ; \alpha_{3}<0\right)$, water quality $\left(\beta_{1}<0 ; \beta_{3}<0\right)$, air quality $\left.\left(\gamma_{1}<0\right) ; \gamma_{3}<0\right)$, land cover quality $\left(\delta_{1}<0 ; \delta_{3}<0\right)$. Furthermore, an increase of education and income level (in the square form) finally has a positive relationship to environmental quality $\left(\alpha_{2}>0 ; \alpha_{4}>0\right)$, water quality $\left(\beta_{2}>0 ; \beta_{4}>0\right)$, air quality $\left.\left(\gamma_{2}>0\right) ; \gamma_{4}>0\right)$, and land cover quality $\left(\delta_{2}>0 ; \delta_{4}>0\right)$.

\section{Data}

This study uses secondary data on the environmental quality index, and its derivatives, including water, air, and land cover quality index taken from environment quality index reports of Indonesia's Ministry of Environment and Forestry. Moreover, the mean years of schooling data published by Indonesia's Central Bureau of Statistics and GRDP per capita at constant 2010 prices source from Indonesia's Central Bureau of Statistics. At this point, Indonesia consists of 34 provinces. However, data on the mean years of schooling and GRDP per capita at constant 2020 prices were only available in 2013; data on the environmental quality index was only available in 2017 . The data sample used is 264 structured observations in the form of balanced panel data where $\mathrm{N}$ (number of provinces) $=33$ provinces and $\mathrm{T}$ (number of observation time series) $=8$ years. Besides the primary sample, a subsample model is divided based on Java Island's location (48 observations) and outside Java Island (216 observations).

Summary of descriptive statistics reported in Table 1 shows that Java Island has lower environmental, water, air, and land cover quality index values compared to Indonesia and outside Java Island. On the contrary, Java Island has higher mean years of schooling, GRDP per capita at constant 2010 prices, household consumption expenditures at constant 2010 prices, a higher percentage of urban areas, and a higher population than Indonesia and outside Java. In conclusion, areas with higher mean years of schooling, GRDP per capita at constant 2010 prices, household consumption expenditures at constant 2010 prices, percentage of the population of urban areas, and the number of populations will have a lower environmental, water, air, and land cover quality.

Table 1. Descriptive Statistics Samples of Indonesia. Java. and Outside Java

\begin{tabular}{lrrrrrr}
\hline & \multicolumn{2}{c}{ Indonesia } & \multicolumn{2}{c}{ Java } & \multicolumn{2}{c}{ Outside Java } \\
\hline & Observations & Mean & Observations & Mean & Observations & Mean \\
\hline Envi (Index) & 264 & 66.603 & 48 & 52.479 & 216 & 69.742 \\
Water (Index) & 264 & 59.516 & 48 & 46.683 & 216 & 62.368 \\
Air (Index) & 264 & 84.683 & 48 & 71.915 & 216 & 87.521 \\
Land (Index) & 264 & 58.350 & 48 & 42.250 & 216 & 61.928 \\
Educ (Years) & 264 & 7.985 & 48 & 8.294 & 216 & 7.916 \\
Income (Million Rupiah) & 264 & 36.379 & 48 & 45.973 & 216 & 34.247 \\
HHC (Trillion Rupiah) & 264 & 145 & 48 & 519 & 216 & 61.600 \\
Urban (Percent) & 264 & 43.873 & 48 & 66.917 & 216 & 38.752 \\
Pop (Million People) & 264 & 7.650 & 48 & 24 & 216 & 4.005 \\
\hline
\end{tabular}

\section{Results and Discussions}

\section{Empirical Results}

The relationship between education and income level on environmental quality and each component was analyzed using panel data regression with generalized least square 
estimation methods in equations (1) to (4) as depicted in Table 2. The estimation results show that the mean years of schooling in Indonesia has a negative relationship to the quality of the environment (significance level at 1 percent) with a coefficient of 4.645; has a negative relationship to air quality (significance level at 10 percent) with a coefficient of 1.335 and has a negative relationship to the quality of land cover (significance level at 1 percent) with a coefficient of 14.324. On the other hand, the square of mean years of schooling in Indonesia has a positive relationship to environmental quality (significance level at 1 percent) with a coefficient of 1.127 ; has a positive relationship to air quality (significance level at 10 percent) with a coefficient of 0.324 and has a positive relationship to the quality of land cover (significance level at 1 percent) with a coefficient of 3.454. Meanwhile, the mean years of schooling and the mean years of schooling squared in Indonesia have no relationship to water quality.

\section{Table 2. Relationship between Education Level and Income on Environmental Quality in Indonesia}

\begin{tabular}{|c|c|c|c|c|}
\hline \multicolumn{5}{|c|}{ Indonesia } \\
\hline & InEnvi & lnWater & $\ln A i r$ & InLand \\
\hline $\operatorname{lnEduc}$ & $-4.645 * * *$ & 3.51 & $-1.335 *$ & $-14.324 * * *$ \\
\hline sqlnEduc & $1.127 * * *$ & -0.838 & $0.324 *$ & $3.454 * * *$ \\
\hline lnIncome & $1.466 * * *$ & $2.890 * * *$ & $0.786 * * *$ & $0.784 * *$ \\
\hline sqlnIncome & $-0.061 * * *$ & $-0.133 * * *$ & $-0.037 * * *$ & -0.019 \\
\hline $\ln \mathrm{HHC}$ & $-0.299 * * *$ & -0.015 & $-0.097 * * *$ & $-0.682 * * *$ \\
\hline lnUrban & $-0.153 * * *$ & $-0.153 * * *$ & -0.011 & $-0.172 * * *$ \\
\hline $\ln$ Pop & $0.254 * * *$ & -0.024 & $0.054 *$ & $0.612 * * *$ \\
\hline _Cons & $2.529 *$ & $-13.677 * * *$ & $2.617 *$ & $16.410 * * *$ \\
\hline $\mathrm{N}$ & 264 & 264 & 264 & 264 \\
\hline Wald Chi2 (14) & 1.060 .46 & 220.18 & 295.79 & 768.45 \\
\hline Prob > Chi2 & 0 & 0 & 0 & 0 \\
\hline
\end{tabular}

GRDP per capita based on constant 2010 prices in Indonesia has a positive relationship to environmental quality (significance level at 1 percent) with a coefficient of 1.466; has a positive relationship to water quality (significance level at 1 percent) with a coefficient of 2.89; has a positive relationship to air quality (significance level at 1 percent) with a coefficient of 0.786 ; has a positive relationship to the quality of land cover (significance level at 5 percent) with a coefficient of 0.784 . Then, the square GRDP per capita at constant prices in 2010 in Indonesia has a negative relationship to environmental quality (significance level at 1 percent) with a coefficient of 0.061 ; has a negative relationship to water quality (significance level at 1 percent) with a coefficient of 0.133 ; has a negative relationship with air quality (significance level at 1 percent) with a coefficient of 0.037. Meanwhile, the square of GRDP per capita at constant prices in 2010 in Indonesia has no relationship to land cover quality.

There are unique findings from the regression results to air quality with the Java Island sample (see Table 3). The mean years of schooling in Java positively correlate to air quality (significance level at 10 percent) with a coefficient of 11.190. On the other hand, the square of mean years of schooling in Java negatively relates to air quality (significance level at 1 percent) with a coefficient of 3.423. GRDP per capita based on constant 2010 prices in Java Island negatively relates to air quality (significance level at 1 percent) with a coefficient of 10.376. The square of GRDP per capita based on constant 2010 prices in Java Island has a negative relationship to air quality (significance level at 1 percent) with a coefficient of 0.294 . 
The mean years of schooling in Java have a negative relationship to the quality of land cover (significance level at 5 percent) with a coefficient of 13.597. Furthermore, the squared of mean years of schooling in Java has a positive relationship to the quality of land cover (significance level at 5 percent) with a coefficient of 3.425. Subsequently, GRDP per capita based on constant 2010 prices in Java Island have a positive relationship with the quality of land cover (significance level at 1 percent) with a coefficient of 5.734. Then, the square of GRDP per capita at constant prices in 2010 in Java Island negatively relates to the quality of land cover (significance level at 1 percent) with a coefficient of 0.260 . Meanwhile, the mean years of schooling, the square of mean years of schooling, GRDP per capita based on constant prices in 2010, and the square of GRDP per capita at constant prices in 2010 in Java has no relationship to environmental quality and water quality.

Table 3. Relationship between Education Level and Income on Environmental Quality in Java

\begin{tabular}{|c|c|c|c|c|}
\hline \multicolumn{5}{|c|}{ Java } \\
\hline & InEnvi & InWater & $\ln \mathrm{Air}$ & lnLand \\
\hline $\operatorname{lnEduc}$ & -1.395 & -3.937 & $11.190 *$ & $-13.597 * *$ \\
\hline sqlnEduc & 0.113 & 0.694 & $-3.423 * * *$ & $3.425 * *$ \\
\hline lnIncome & -0.038 & 8.048 & $-10.376 * * *$ & $5.734 * * *$ \\
\hline sqlnIncome & -0.026 & -0.158 & $0.294 * * *$ & $-0.260 * * *$ \\
\hline $\ln \mathrm{HHC}$ & 0.603 & $-4.826 * * *$ & $4.359 * * *$ & -0.261 \\
\hline lnUrban & -0.160 & -0.433 & 0.113 & $-0.619 *$ \\
\hline $\operatorname{lnPop}$ & -0.671 & $4.947 * * *$ & $-4.696 * * *$ & 0.354 \\
\hline _Cons & $9.758^{*}$ & $-46.656 * *$ & $64.389 * * *$ & $-12.641 *$ \\
\hline $\mathrm{N}$ & 48 & 48 & 48 & 48 \\
\hline Wald Chi2 (14) & 1679.73 & 217.59 & 227.15 & 790.17 \\
\hline Prob > Chi2 & 0.00 & 0.00 & 0.00 & 0.00 \\
\hline
\end{tabular}

The regression analysis results with samples outside Java Island are almost the same as the findings with Indonesia's sample (see Table 4). For starters, we start by analyzing the relationship to environmental quality. The mean years of schooling outside Java Island have a negative relationship (significance level at 1 percent) with a coefficient of 8.716. However, the square of mean years of schooling has a positive relationship (significance level at 1 percent) with a coefficient of 2.172. On the contrary, GRDP per capita based on constant prices in 2010 has a positive relationship (significance level at 1 percent) with a coefficient of 0.787; but the square of GRDP per capita based on constant prices in 2010 has a negative relationship (significance level at 1 percent) with a coefficient of 0.031 .

Furthermore, we analyze the relationship to air quality. The mean years of schooling outside Java Island have a negative relationship (significance level at 10 percent) with a coefficient of 1.413. Nonetheless, the square of mean years of schooling has a positive relationship (significance level at 10 percent) with a coefficient of 0.348 . On the contrary, GRDP per capita based on constant prices in 2010 has no relationship. Nevertheless, the square of GRDP per capita based on constant prices in 2010 has a negative relationship (significance level at 10 percent) with a coefficient of 0.017 .

Next, we analyze the relationship to land cover quality. The mean years of schooling outside Java Island have a negative relationship (significance level at 1 percent) with a coefficient of 22.797. Nevertheless, the square of mean years of schooling has a positive relationship (significance level at 1 percent) with a coefficient of 5.636. On the contrary, GRDP per capita is based on constant prices in 2010, and the square of GRDP per capita based on constant prices in 2010 has no relationship to land cover quality. Lastly, outside Java Island, the mean years of schooling, the square form of mean years of schooling, 
GRDP per capita based on constant prices in 2010, and the square of GRDP per capita based on constant prices in 2010 have no relationship to water cover quality.

Table 4. Relationship between Education Level and Income on Environmental Quality Outside Java

\begin{tabular}{|c|c|c|c|c|}
\hline \multicolumn{5}{|c|}{ Outside Java } \\
\hline & InEnvi & lnWater & lnAir & lnLand \\
\hline $\operatorname{lnEduc}$ & $-8.716 * * *$ & 1.008 & $-1.413 *$ & $-22.797 * * *$ \\
\hline sqlnEduc & $2.172 * * *$ & -0.242 & $0.348 *$ & $5.636 * * *$ \\
\hline lnIncome & $0.787 * * *$ & 0.997 & 0.346 & 0.475 \\
\hline sqlnIncome & $-0.031 * * *$ & -0.047 & $-0.017 *$ & -0.008 \\
\hline $\ln \mathrm{HHC}$ & $-0.194 * * *$ & $0.133^{*}$ & -0.029 & $-0.558 * * *$ \\
\hline lnUrban & $-0.120 * * *$ & -0.040 & $0.030 * * *$ & $0.239 * * *$ \\
\hline $\operatorname{lnPop}$ & $0.132 * * *$ & -0.138 & -0.008 & $0.418 * * *$ \\
\hline _Cons & $10.092 * * *$ & -2.090 & $4.655 * * *$ & $27.560 * * *$ \\
\hline $\mathrm{N}$ & 216 & 216 & 216 & 216 \\
\hline Wald Chi2 (14) & 320.54 & 184.98 & 235.42 & 700.61 \\
\hline Prob $>$ Chi 2 & 0 & 0 & 0 & 0 \\
\hline
\end{tabular}

Note: Figures in brackets indicate $\mathrm{t}$ values, ${ }^{* *}, * *$, and $*$ at $1 \% 5 \%$ and $10 \%$ levels of statistical significance, respectively.

\section{Discussions}

In Indonesia's sample, air, land cover, and environmental quality would improve if the mean years of schooling were doubled from current conditions. While, environmental, water, air, and land cover quality will increase if the GRDP per capita at constant 2010 prices are maintained in current conditions. In the sample of Java Island, the air quality of the six provinces in Java Island will have a better relationship if the mean years of schooling are maintained in the current condition and the GRDP per capita at constant 2010 prices are increased by two times from the current condition. Moreover, the quality of land cover in Java Island will have a better relationship if the mean years of schooling were doubled over the current condition and the GRDP per capita at constant 2010 prices is maintained at its current condition. This finding is unique because there is a dilemma in choosing the best policy to improve Java's environmental quality.

Nevertheless, the land cover quality index's value has a higher contribution than the water quality index and air quality index to environmental quality index. A sample of 27 provinces outside Java indicates that air, land cover, and environmental quality have a stronger relationship with mean years of schooling that was increased by two times than the current condition. Moreover, the quality of the environment outside Java Island also has a better relationship if the GRDP per capita is retained like the current condition. This finding can strengthen previous research arguments that higher education can positively correlate to environmental quality. Increasing education in the early stages will create an increase in job opportunities (Balaguer \& Cantavella, 2018), so there will be an increase in people's income that will ultimately result in increased consumption of non-renewable energy, which is fossil fuel (Waslekar, 2014; Yazdi \& Dariani, 2019; Zafar et al., 2020)(Waslekar, 2014; Yazdi \& Dariani, 2019; Zafar et al., 2020). This is followed by national priority in pursuing rapid economic development by having many industries with non-environmental-friendly technologies (Zhang et al., 2017). Consumption of nonrenewable energy resources occurs continuously, creating a depletion in fossil fuel stocks (Kurniawan \& Managi, 2018) and negative externalities at the regional level (Baek, 2016). These negative externalities are air pollution and water pollution, which worsen the environment's quality (Balaguer \& Cantavella, 2018; Kasman \& Duman, 2015; J. Li et al., 2019; Waslekar, 2014). The environmental damage has created anxiety about the economy's sustainability that has passed the environment's carrying capacity. This anxiety 
is followed by the community's initial awareness of the importance of protecting the environment, so there will be a demand for environmental education in the educational curriculum (Zafar et al., 2020).

When there is an increase in higher education, people's behavior will be changed to be more pro-environmental, which is supported by an increase in contributions in finding solutions to environmental problems resulted in a change in people's consumption and lifestyle to a more sustainable direction (Ahmed et al., 2020; Hoang \& Kato, 2016; Kahyaoğlu, 2014; Sumargo, 2018; Varela-Candamio et al., 2018; Zafar et al., 2020; Zsóka et al., 2013). This behavior can increase the incentives and the number of households willing to pay to support environmental sustainability (Tianyu \& Meng, 2020). This enables people and workers who have ideas about energy efficiency and environmental protection so that people demand environmental sustainability by asking for pro-environmental law enforcement (Zafar et al., 2020), which in turn will produce an improvement in the quality of the environment (Balaguer \& Cantavella, 2018; Hoang \& Kato, 2016; Tianyu \& Meng, 2020; Varela-Candamio et al., 2018; Zafar et al., 2020; Zsóka et al., 2013).

Unfortunately, we identified that higher income in Indonesia, Java, and outside Java are correlated with the worsened environmental quality. Compared to previous studies, this may happen if there is no policy to regulate negative externalities from environmental pollution. This pollution is caused by many industries that still use conventional technology, and the cost of responsibility for environmental pollution is not included in production costs. As a result, the industry has not turned to environmentally friendly energy use and production methods (Balaguer \& Cantavella, 2018; Zhang et al., 2017). Then, there is no incentive mechanism in the form of subsidies and tax breaks (Hove \& Tursoy, 2019; Rahman \& Vu, 2020) and no disincentives for polluting activities through the imposition of environmental taxes and strict regulations for a cleaner and healthier environment (Hove \& Tursoy, 2019; Zhang et al., 2017). So, the industry continues to pursue higher incomes with non-environmental-friendly technologies, energy resources, and production methods which will worsen the quality of Indonesia's environment.

\section{Conclusion}

The results of panel data regression analysis concluded that the best step to improving environmental quality is by improving education and maintaining the income level in the current state. The finding is supported by the descriptive analysis showing that provinces with higher mean years of schooling, GRDP per capita in constant prices in 2010, household consumption expenditures, percentage of the population of urban areas, as well as the number of populations, will have lower environmental quality, lower water quality, lower air quality, and lower land cover quality. Nevertheless, it implied that the hypothesis that a higher level of education in the long term and a higher level of income in the long run will improve environmental quality has not been proven in Indonesian regional provinces.

Indonesia's Ministry of National Development Planning has stated that Indonesia is committed to achieving the SDGs in implementing sustainable development at the national level. However, Indonesia's efforts to achieve sustainable development have several challenges. First, Indonesia has entered the middle-income trap. Second, there is a problem with a low-educated workforce. Third, Indonesia has experienced a degradation in the environment's quality, hindering sustainable economic growth.

Therefore, Indonesia should carry out development under a business scenario to develop the country towards sustainable development. This research advises that Indonesia needs to improve the quantity and quality of education to have human capital that cares about sustainable development in consumption and production activities. Furthermore, concerning the trade-off between regional income and environmental quality, 
the Government of Indonesia should establish an incentives and disincentives mechanism for all economic actors in using energy resources and production techniques that are environmentally friendly. However, the policy still must be adjusted concerning the suitability for taking Indonesia's diversity as an archipelago into account. In the long-term horizon, the policy is expected to create regional sustainable development of Indonesia with better environmental quality and preserving regional economic growth.

\section{References}

Ahmed, Z., Asghar, M. M., Malik, M. N., \& Nawaz, K. (2020). Moving towards a sustainable environment: The dynamic linkage between natural resources, human capital, urbanization, economic growth, and ecological footprint in China. Resources Policy, 67(April). doi:10.1016/j.resourpol.2020.101677.

Baek, J. (2016). A new look at the FDI-income-energy-environment nexus: Dynamic panel data analysis of ASEAN. Energy Policy, 91, 22-27. doi:10.1016/j.enpol.2015.12.045.

Balaguer, J., \& Cantavella, M. (2018). The role of education in the Environmental Kuznets Curve. Evidence from Australian data. Energy Economics, 70, 289-296. doi:10.1016/j.eneco.2018.01.021.

Basri, M. C., Rahardja, S., \& Fitrania, S. N. (2016). Not a trap, but slow transition? Indonesia's pursuit to high income status. Asian Economic Papers, 15(2), 1-23. doi:10.1162/ASEP_a_00422.

BPS. 2020. Penduduk berumur 15 tahun ke atas menurut pendidikan tertinggi yang ditamatkan dan jenis kegiatan selama seminggu yang lalu, 2008-2020. Retrieved from: https://www.bps.go.id/statictable/2016/04/05/1909/penduduk-berumur-15-tahun-ke-atas-menurutpendidikan-tertinggi-yang-ditamatkan-dan-jenis-kegiatan-selama-seminggu-yang-lalu-2008-2020.html.

Gujarati, D. N., \& Porter, D. C. (2013). Single-equation regression models. In Introductory econometrics: A practical approach.

Hoang, T. T. P., \& Kato, T. (2016). Measuring the effect of environmental education for sustainable development at elementary schools: A case study in Da Nang city, Vietnam. Sustainable Environment Research, 26(6), 274-286. doi:10.1016/j.serj.2016.08.005.

Hove, S., \& Tursoy, T. (2019). An investigation of the environmental Kuznets curve in emerging economies. Journal of Cleaner Production, 236. doi:10.1016/j.jclepro.2019.117628.

Kahyaoğlu, M. (2014). The research of the relationship between environmentally aware prospective teachers' qualities and self efficacy beliefs towards environmental education. Procedia - Social and Behavioral Sciences, 116, 4493-4497. doi:10.1016/j.sbspro.2014.01.973.

Kasman, A., \& Duman, Y. S. (2015). CO2 emissions, economic growth, energy consumption, trade and urbanization in new EU member and candidate countries: A panel data analysis. Economic Modelling, 44, 97-103. doi:10.1016/j.econmod.2014.10.022.

Kroll, C., \& Zipperer, V. (2020). Sustainable development and populism. Ecological Economics, 176. doi:10.1016/j.ecolecon.2020.106723.

Kurniawan, R., \& Managi, S. (2018). Economic growth and sustainable development in Indonesia: An assessment. Bulletin of Indonesian Economic Studies, 54(3), 339-361. doi:10.1080/00074918.2018.1450962.

Li, J., Luo, Y., \& Wang, S. (2019). Spatial effects of economic performance on the carbon intensity of human well-being: The environmental Kuznets curve in Chinese provinces. Journal of Cleaner Production, 233, 681-694. doi:10.1016/j.jclepro.2019.05.396.

Li, L., Shan, Y., Lei, Y., Wu, S., Yu, X., Lin, X., \& Chen, Y. (2019). Decoupling of economic growth and emissions in China's cities: A case study of the Central Plains urban agglomeration. Applied Energy, 244, 36-45. doi:10.1016/j.apenergy.2019.03.192.

Liang, W., \& Yang, M. (2019). Urbanization, economic growth and environmental pollution: Evidence from China. Sustainable Computing: Informatics and Systems, 21, 1-9. doi:10.1016/j.suscom.2018.11.007.

Lima, M. G. B., Kissinger, G., Visseren-Hamakers, I. J., Braña-Varela, J., \& Gupta, A. (2017). The sustainable development goals and REDD+: assessing institutional interactions and the pursuit of synergies. International Environmental Agreements: Politics, Law and Economics, 1744), 589-606. doi:10.1007/s10784-017-9366-9. 


\section{The Relationship of Education and Regional Income Level on Environmental Quality...}

Lubis, R. F., \& Saputra, P. M. A. (2016). The middle-income trap: Is there a way out for asian countries? Journal of Indonesian Economy and Business, 29(3), 273-287. doi:10.22146/jieb.10316.

Patole, M. (2018). Localization of SDGs through disaggregation of KPIs. Economies, 6(1). doi:10.3390/economies6010015.

Rahman, M. M. (2017). Do population density, economic growth, energy use and exports adversely affect environmental quality in Asian populous countries? Renewable and Sustainable Energy Reviews, 77, 506-514. doi:10.1016/j.rser.2017.04.041.

Rahman, M. M., \& Vu, X. B. (2020). The nexus between renewable energy, economic growth, trade, urbanization and environmental quality: A comparative study for Australia and Canada. Renewable Energy, 155, 617-627. doi:10.1016/j.renene.2020.03.135.

Salvia, A. L., Leal Filho, W., Brandli, L. L., \& Griebeler, J. S. (2019). Assessing research trends related to Sustainable Development Goals: local and global issues. Journal of Cleaner Production, 208, 841-849. doi:10.1016/j.jclepro.2018.09.242.

Scheyvens, R., Banks, G., \& Hughes, E. (2016). The private sector and the SDGs: The need to move beyond' business as usual.' Sustainable Development, 24(6), 371-382. doi:10.1002/sd.1623.

Setyawan, A., Hadijati, M., \& Switrayni, N. W. (2019). Analisis masalah heteroskedastisitas menggunakan generalized least square dalam analisis regresi. Eigen Mathematics Journal, 2(2), 61-72. doi:10.29303/emj.v1i2.43.

Sumargo, B. (2018). Comparing better environmental knowledge based on education and income using the odds ratio. Procedia Computer Science, 135, 105-112. doi:10.1016/j.procs.2018.08.155.

Tianyu, J., \& Meng, L. (2020). Does education increase pro-environmental willingness to pay? Evidence from Chinese household survey. Journal of Cleaner Production, 275. doi:10.1016/j.jclepro.2020.122713.

Varela-Candamio, L., Novo-Corti, I., \& García-Álvarez, M. T. (2018). The importance of environmental education in the determinants of green behavior: A meta-analysis approach. Journal of Cleaner Production, 170, 1565-1578. doi:10.1016/j.jclepro.2017.09.214.

Waslekar, S. S. (2014). World environmental kuznets curve and the global future. Procedia - Social and Behavioral Sciences, 133, 310-319. doi:10.1016/j.sbspro.2014.04.197.

Yao, S., Zhang, S., \& Zhang, X. (2019). Renewable energy, carbon emission and economic growth: A revised environmental Kuznets Curve perspective. Journal of Cleaner Production, 235, 1338-1352. doi:10.1016/j.jclepro.2019.07.069.

Yazdi, S. K., \& Dariani, A. G. (2019). CO2 emissions, urbanization and economic growth: evidence from Asian countries. Economic Research-Ekonomska Istrazivanja, $32(1), \quad 510-530$. doi:10.1080/1331677X.2018.1556107.

Zafar, M. W., Shahbaz, M., Sinha, A., Sengupta, T., \& Qin, Q. (2020). How renewable energy consumption contribute to environmental quality? The role of education in OECD countries. Journal of Cleaner Production, 268. doi:10.1016/j.jclepro.2020.122149.

Zhang, C., Wang, Y., Song, X., Kubota, J., He, Y., Tojo, J., \& Zhu, X. (2017). An integrated specification for the nexus of water pollution and economic growth in China: Panel cointegration, long-run causality and environmental Kuznets curve. Science of the Total Environment, 609, 319-328. doi:10.1016/j.scitotenv.2017.07.107.

Zinkernagel, R., Evans, J., \& Neij, L. (2018). Applying the SDGs to cities: Business as usual or a new dawn? Sustainability, 1099). doi:10.3390/su10093201.

Zsóka, Á., Szerényi, Z. M., Széchy, A., \& Kocsis, T. (2013). Greening due to environmental education? Environmental knowledge, attitudes, consumer behavior and everyday pro-environmental activities of Hungarian high school and university students. Journal of Cleaner Production, 48, 126-138. doi:10.1016/j.jclepro.2012.11.030. 